\title{
The Effect of Realistic Mathematical Approach Using Malay Culture-Based Learning Tools on Mathematics Learning Outcomes of Junior High School 6 Pekanbaru
}

\author{
Astri Wahyuni ${ }^{1}$, Yaya Sukjaya Kusumah ${ }^{2}$, Surgawi Pertiwi ${ }^{3}$ \\ ${ }_{1,2}$ Program Studi Pendidikan Matematika, Universitas Pendidikan Indonensia, ${ }^{3}$ SMP Negeri 6 Pekanbaru, \\ J1. Dr. Setia Budhi No. 229, Bandung, Jawa Barat 40154, Indonesia \\ astriwahyuni@upi.edu
}

\begin{abstract}
The purpose of this study was to determine the effect of Realistic Mathematics Approach on the learning outcomes of seventh grade students of Junior High School 6 Pekanbaru with quasi-experimental. There are two classes that will be sampled, namely the experimental and control classes with purposive sampling as a data collection technique. The data collection method used is a test with descriptive and inferential statistical data analysis techniques. Descriptive statistical analysis technique was used to describe the power obtained from the measurement results of the dependent variable, namely learning outcomes, inferential statistical analysis techniques were used to analyze sample data (pre-test and post-test). The results of descriptive statistical analysis showed that the average pre-test for the experimental and control classes were 50.10 and 54.31, while the posttest averages for the experimental and control classes were 76.79 and 68.13. In this study, the data were normally distributed, with a homogeneity value of 0.752 and when tested $t$ the result was $0.002<0.05$, so it can be concluded that there is an effect of realistic mathematics approach on student learning outcomes.
\end{abstract}

Keywords: PMR, learning outcomes

\begin{abstract}
Abstrak
Tujuan penelitian ini yakni mengetahui pengaruh Pendekatan Matematika Realistik (PMR) pada hasil belajar siswa kelas VII SMP Negeri 6 Pekanbaru dengan eksperimen semu. Terdapat dua kelas yang akan diambil sampel yakni kelas eksperimen dan kontrol dengan purposive sampling sebagai teknik pengambilan data. Metode pengumpulan data yang dipakai yakni tes dengan teknik analisis data statistik deskriptif dan inferensial. Teknik analisis statistik deskriptif digunakan untuk menjabarkan daya yang diperoleh dari hasil pengukuran variabel terikat yaitu hasil belajar, teknik analisis statistik inferensial digunakan untuk menganalisis data sampel (pre-test dan post-test). Hasil analisis statistik deskriptif di dapatkan rata-rata pre-test kelas eksperimen dan kontrol ialah 50,10 dan 54,31, sedangkan rata-rata post-test kelas eksperimen dan kontrol ialah 76,79 dan 68,13. Pada penelitian ini data berdistribusi normal, dengan nilai homogenitas 0,752 dan saat diuji t diperoleh hasilnya 0,002 $<0,05$ sehingga dapat disimpulkan jika ada pengaruh pendekatan matematika realisik terhadap hasil belajar siswa.
\end{abstract}

Kata kunci: PMR, Hasil Belajar

Copyright (c) 2021 Astri Wahyuni, Yaya Sukjaya Kusumah, Surgawi Pertiwi

$\triangle$ Corresponding author: Astri Wahyuni

Email Address: astriwahyuni@upi.edu (Jl. Dr. Setia Budhi No. 229, Bandung, Jawa Barat 40154, Indonesia)

Received 09 September 2021, Accepted 13 October 2021, Published 21 November 2021

\section{INTRODUCTION}

Education is an intermediary that makes the Indonesian nation more resilient, independent, characterized and highly competitive. Education is a right, where everyone has the right to education which aims to build life and can live with dignity (Qian, 2019). Education as a foundation provides knowledge and makes students' potential develop, so improving the quality of education is necessary in to achieve educational goals. It is hoped that education can make a better generation and be able to fight the challenges of the future era (Rezeki et al., 2020).

Some efforts to find out whether the education is quality is the success of learning in the classroom. This success is determined by several factors, for example, the learning approach applied by 
the teacher. By determining and implementing the right learning approach can produce maximum learning outcomes. In addition to applying the right approach, teachers are also required to make learning interesting and meaningful so that what has been taught by the teacher can be easily understood and remembered by students. One of the lessons that must be learned in learning is mathematics.

Mathematics has a very good position, because the benefits provided by knowledge are many (Zafrullah \& Zetriuslita, 2021). Mathematics is an interdisciplinary subject, because mathematics is related to all aspects of everyday life (Sánchez-Compaña et al., 2020). The role of mathematics is very important because it can advance the mindset (Nunes \& Bryan, 2000). The development of technology and advances in scientific progress make mathematics education must be improved (Wahyuni \& Abadi, 2014). The context that can arouse students' motivation to learn is an interesting context (Wijaya, 2012). Therefore, combining appropriate learning approaches and contexts that can make students interested and meaningful is the best way to improve student learning outcomes.

Based on the results of researcher interviews with teachers at SMPN 6 Pekanbaru, information was obtained that teachers were not accustomed to using a learning approach that involved student activity in learning, teachers had never used learning tools designed based on Riau Malay culture, namely the culture closest to students. It is also known that student learning outcomes are still low, this must be considered so that other learning problems do not arise that have a negative impact on the academic achievement of students.

In this study, researchers designed teaching materials based on Riau Malay culture with the selection of interesting contexts in learning mathematics. Where culture also contains knowledge . Where culture also contains knowledge. In line with the opinion of E.B Tyler (Binsar et al., 2011) Culture is the whole that contains science, belief, art, or other abilities, so that culture has a complex thing.

Many learning approaches can be linked to culture, for example the Realistic Mathematics Approach or Pendekatan Matematika Realistik (PMR). Realistic Mathematics Approach (PMR) is a learning approach for students by learning directly with the surrounding environment (Bunga et al., 2016). Realistic Mathematics Approach (PMR) is learning by conveying direct experience (Rajagukguk \& Hazrati, 2021). Realistic Mathematics Approach aims to make learning more interesting by introducing learning to this subject through problems related to which problems exist in the knowledge of students. (Arsaythamby \& Zubainur, 2014).

Linking mathematics material to the cultural context is very important because by teaching mathematics material from the local culture, it will be easy for students to understand? Why is that? Because culture is close to children's lives and exists in everyday life, students must know the context of the culture being studied. Thus, students will more easily understand the subject matter and have an impact on increasing mastery of the material and increasing student learning outcomes.

In this study, the culture associated with PMR is Riau Malay weaving. In the learning device, mathematical material related to Riau Malay weaving culture is presented, complete with real pictures 
of woven fabrics and abstraction steps for taking mathematical concepts so that they can help students understand the material. Malay weaving in Riau has a mathematical shape or pattern so that it is easy to relate to mathematical material. Another thing that is achieved by teachers in conducting culture-based research is the introduction of local culture to students, so that students understand the culture. Therefore, researchers want to see the effect of a realistic mathematical approach using teaching materials based on Malay weaving motifs in Riau on students.

\section{METHOD}

\section{Research Form}

This study was a quasi-experimental with two classes namely the experimental and control classes. The experimental class given treatment by applying Realistic Mathematics Approach, while the control class applies conventional learning, namely learning that is usually carried out by teachers as described in the conventional learning stage.

\section{Research Design}

The quasi-experimental design used by researcher is the Nonequivalent Control Group Design. With the experimental group and the control group not chosen random (Sugiyono, 2015). Research design from Setyosari (2013) depicted in the table.

Table 1. Research Design

\begin{tabular}{|ccc|}
\hline $\mathrm{O}_{1}$ & $\mathrm{X}$ & $\mathrm{O}_{2}$ \\
\hline $\mathrm{O}_{3}$ & & $\mathrm{O}_{4}$ \\
\hline
\end{tabular}

Information:

$\mathrm{X} \quad$ : Experimental class learning model treatment

O1 : Experimental class before giving treatment

O3 : Kelas kontrol sebelum pemberian perlakuan

$\mathrm{O} 2$ : Control class before giving treatment

O4 : Control class after treatment

\section{Research Variables}

Research variables are values of people or activities that have certain variations that have been designed by researchers to be studied and will then be concluded (Sudaryono, 2016). In this study, two research variables were used, namely the independent variable and the dependent variable. The independent variable is a variable that affects or is the cause of a change or occurrence of the dependent variable (Sugiyono, 2013). In this study, the independent variable is the Realistic Mathematics Approach. While the dependent variable is a variable that because of the independent variable (Sugiyono, 2013). The dependent variable is the result of learning mathematics from students. 


\section{Population and Research Sample}

The population is all of the research subjects (Arikunto, 2013). In this study, the population was all 7th grade students of Junior High School 6 Pekanbaru in the 2020/2021 academic year. The sample is a part of the population (Sudaryono, 2016). The sample in this study was taken using purposive sampling. Purposive sampling is a sampling technique with certain considerations (Martono, 2013). The sample in this study was class $\mathrm{VII}_{2}$ and $\mathrm{VII}_{4}$ seen from the average student test results which were not much different. Class $\mathrm{VII}_{2}$ as the experimental class and class $\mathrm{VII}_{4}$ as the control class.

\section{Data Collection Techniques and Instruments}

In this study, the type of data collected is learning outcomes data. This data collection technique is a test technique, data about students' mathematics learning outcomes are collected using a test sheet/question paper instrument in the form of pretest and posttest. The pretest instrument is useful for measuring the initial ability of students' mathematics learning outcomes before being given treatment and the posttest instrument is useful for measuring the ability of students' learning outcomes after being given treatment.

\section{Learning Tools}

The learning tools used in this study were the Learning Implementation Plan (RPP), Student Activity Sheets (LKPD) and quiz questions. All devices used are in accordance with the Realistic Mathematical Approach based on Riau Malay weaving.

\section{Data Analysis Technique}

The learning outcomes referred to in this study are the learning outcomes achieved by students in the cognitive aspect. Student learning outcomes are obtained using a test instrument in the form of description questions, after an assessment and a score is obtained, the final student score will be obtained with the formula:

$$
\text { Final Score }=\frac{(\text { Score Obtained })}{(\text { Maximum Score })} \times 100 \%
$$

Table 2. Student Grade Range

\begin{tabular}{|c|c|}
\hline Number Range (100) & Letter \\
\hline $96,25-100$ & $\mathrm{~A}$ \\
\hline $87,75-96,24$ & $\mathrm{~A}-$ \\
\hline $79,50-87,74$ & $\mathrm{~B}+$ \\
\hline $71,25-79,49$ & $\mathrm{~B}$ \\
\hline $62,75-71,24$ & $\mathrm{~B}-$ \\
\hline $54,50-62,74$ & $\mathrm{C}+$ \\
\hline $46,25-54,49$ & $\mathrm{C}$ \\
\hline $37,75-46,24$ & $\mathrm{C}-$ \\
\hline $29,50-73,74$ & $\mathrm{D}+$ \\
\hline $25,00-29,49$ & $\mathrm{D}$ \\
\hline
\end{tabular}

In this study, there will be three trials, namely normality test, homogeneity test, and hypothesis testing. Normality test data was conducted to determine whether the samples tested were normally 
distributed. The normality of the data was tested using the Shapiro-Wilk test through the SPSS 22 program with $(\alpha)=0.05$. The next is the homogeneity test. Furthermore, researchers need to test whether or not the variance is the same with the homogeneity test. Next is hypothesis testing. Hypothesis testing was conducted to determine the differences in students' mathematics learning outcomes. Hypothesis testing is carried out using the SPSS Independent-Sample T Test program. This is in accordance with the aim of testing the average difference between two unrelated samples. The effect of an independent variable on the dependent variable.

\section{RESULTS AND DISCUSSION}

\section{Results}

The implementation of the pre-test and post-test has been carried out, of the two tests the results are depicted in the image below:

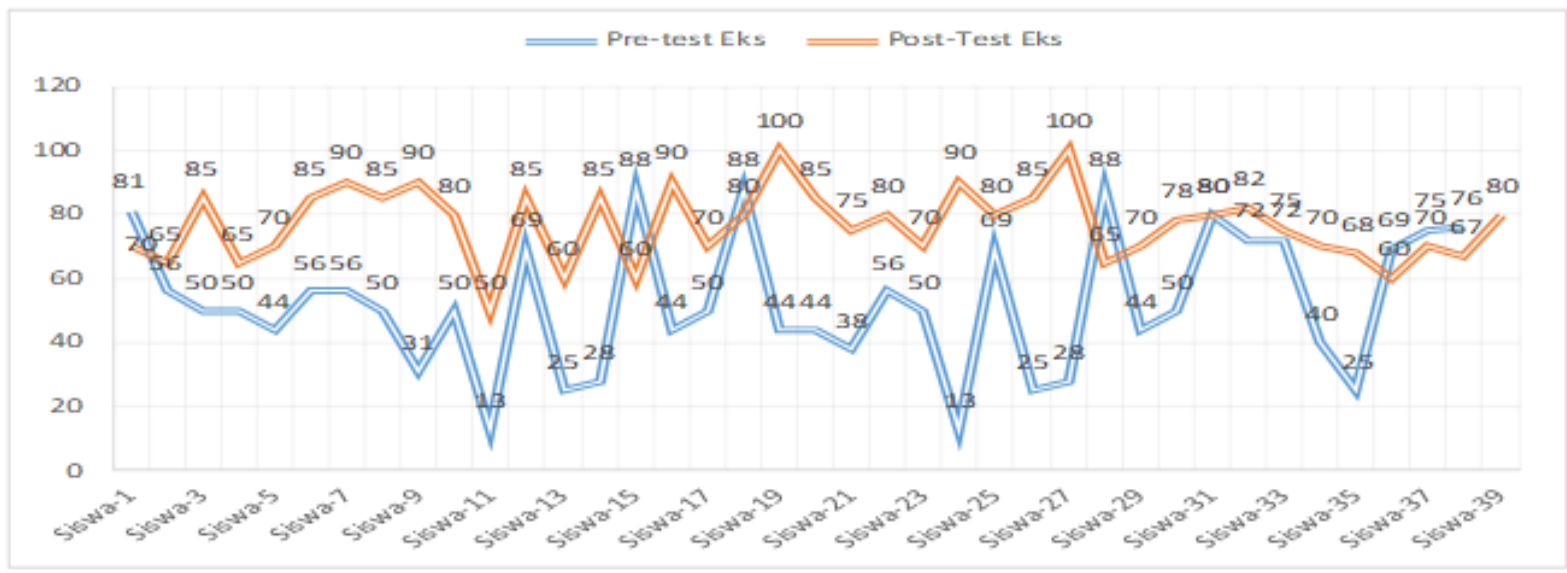

Figure 1. Pre-test and Post-test results in the Experiment class

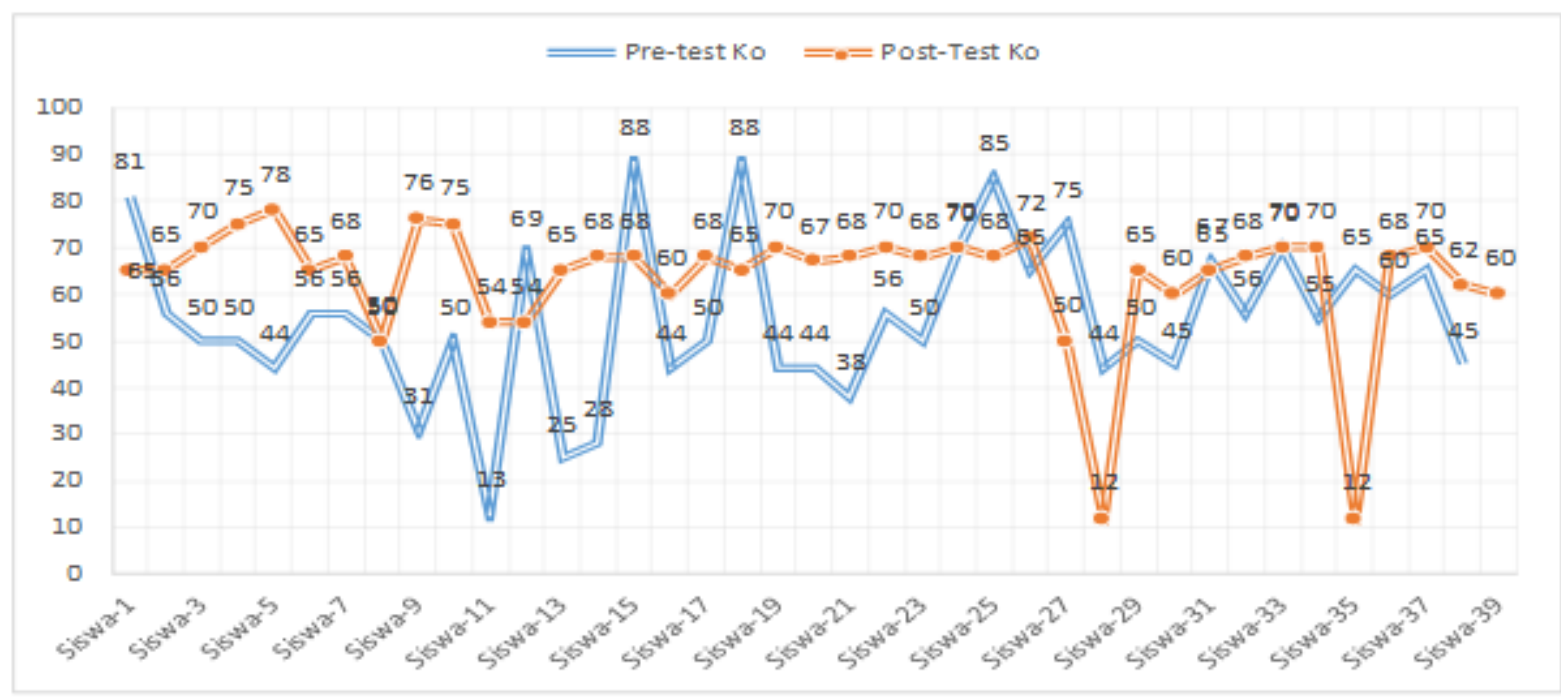

Figure 2. Pre-test and Post-test results in the Control class

The pretest and posttest that have been carried out in the experimental class and control class, it can be analyzed descriptively in Table 3 below: 
Table 3. Pretest and Posttest Result Data for Experiment and Control Class

\begin{tabular}{|c|c|c|c|c|}
\hline \multirow{2}{*}{ Information } & \multicolumn{2}{|c|}{ Pretest } & \multicolumn{2}{c|}{ Posttest } \\
\cline { 2 - 5 } & Experiment & Control & Experiment & Control \\
\hline $\begin{array}{l}\text { Number of } \\
\text { Sample (n) }\end{array}$ & 39 & 39 & 39 & 39 \\
\hline Average $(\bar{x})$ & 52,10 & 54,31 & 76,79 & 63,44 \\
\hline
\end{tabular}

The table above shows that the average pretest of the experimental and control classes is 52.10 and 54.31. However, after being given treatment to the experimental class, it is seen that the posttest data of the experimental class has increased compared to the control class. The results showed that the average posttest of the control class was 63.44 and the average student learning outcomes of the experimental class were 76.79 with higher results. The experimental class increased by 24.69 while the control class increased by 9.13 . With only this descriptive statistical analysis, conclusions cannot be made when there is an influence of planted questions learning strategies on learning outcomes, so an inferential analysis is carried out so that the results obtained will be correct.

\section{Normality Test}

This Normality Test aims to see whether the data from each class is normally distributed or not. Because one of the assumptions that must be met before the homogeneity of variance test is carried out, the data for the two classes must be normally distributed before receiving different treatment. From the calculation results obtained:

Table 4. Output Results of Data Normality Test

\begin{tabular}{|c|c|c|c|c|c|c|c|}
\hline \multicolumn{8}{|c|}{ Tests of Normality } \\
\hline \multirow{3}{*}{} & \multirow{3}{*}{ Kelas } & \multicolumn{2}{|c|}{ Kolmogorov-Smirnov ${ }^{\mathrm{a}}$} & \multicolumn{3}{c|}{ Shapiro-Wilk } \\
\cline { 2 - 8 } & Statistic & Df & Sig. & Statistic & df & Sig. \\
\cline { 2 - 8 } & 1 & .131 & 39 & .091 & .961 & 39 & .188 \\
\cline { 2 - 8 } & 2 & .137 & 39 & .062 & .971 & 39 & .399 \\
\cline { 2 - 8 } & 3 & .127 & 39 & .117 & .972 & 39 & .443 \\
\cline { 2 - 8 } & 4 & .135 & 39 & .069 & .958 & 39 & .154 \\
\hline \multicolumn{7}{|c|}{ a. Lilliefors Significance Correction } \\
\hline
\end{tabular}

Based on the SPSS output with the Shapiro-Wilk test for the experimental class, the pre-test probability value for the experimental class was 0.188 . The probability value of the control class pretest is 0.443 . The post-test value of the experimental class resulted in a probability value of 0.399 while the control class was 0.154 . Because all Sig values obtained are $>0.05$, it can be concluded that all pretest and post-test data, both experimental and control classes, are normally distributed. 
The Effect of Realistic Mathematical Approach Using Malay Culture-Based Learning Tools on Mathematics Learning Outcomes of Junior High School 6 Pekanbaru, Astri Wahyuni, Yaya Sukjaya Kusumah, Surgawi Pertiwi

\section{Homogeneity Test}

Homogeneity test was conducted to find out both classes of variance were homogeneous. In the Levene test of the SPSS 22, the guideline for making a homogeneous variance decision is if the probability value of the mean $>\alpha=0.05$, then the data comes from a population that has the same variance (homogeneous). The results of the calculation of the homogeneity test of the Pre-test data are:

Table 5. Output Results of Pre-test Data Homogeneity Test

\begin{tabular}{|c|c|l|l|l|l|}
\hline \multicolumn{7}{|c|}{ Test of Homogeneity of Variance } \\
\hline \multirow{2}{|c|}{} & $\begin{array}{c}\text { Levene } \\
\text { Statistic }\end{array}$ & df1 & df2 & Sig. \\
\hline $\begin{array}{c}\text { Pretest Learning } \\
\text { Outcomes }\end{array}$ & Based on Mean & 1.738 & 1 & 76 & .191 \\
\cline { 2 - 7 } & Based on Median & 1.283 & 1 & 76 & .261 \\
\cline { 2 - 7 } & $\begin{array}{c}\text { Based on Median and } \\
\text { with adjusted df }\end{array}$ & 1.283 & 1 & 72.234 & .261 \\
\cline { 2 - 7 } & Based on trimmed mean & 1.776 & 1 & 76 & .187 \\
\hline
\end{tabular}

The results of the significant value or the average probability of the pre-test learning outcomes are 0.191 . This means that the significant value is greater than $\alpha=0.05$, so it can be concluded that the data on student learning outcomes has the same or homogeneous variance. While the results of the Posttest data are:

Table 6. Results of the Post-Test Data Homogeneity Test Output

\begin{tabular}{|c|l|l|l|l|l|}
\hline \multicolumn{7}{|c|}{ Test of Homogeneity of Variance } \\
\hline \multirow{3}{*}{$\begin{array}{c}\text { Postets Learning } \\
\text { Results }\end{array}$} & Levene Statistic & df1 & df2 & Sig. \\
\cline { 2 - 7 } & Based on Mean & .101 & 1 & 76 & .752 \\
\cline { 2 - 7 } & $\begin{array}{c}\text { Based on Median and with } \\
\text { adjusted df }\end{array}$ & .081 & 1 & 75.983 & .777 \\
\cline { 2 - 7 } & Based on trimmed mean & .101 & 1 & 76 & .752 \\
\hline
\end{tabular}

It can be seen the significant value or average probability of post-test learning outcomes is 0.752 . This means that the significant value is greater than $=0.05$, so it can be concluded that the data on student learning outcomes has the same variance. So, it can be concluded that the test results in the experimental and control classes have the same variance.

\section{T Test}

The data from the calculation of the normality test and the homogeneity of the learning outcomes of the two classes, it is known that the two data are normally distributed and homogeneous. To test the average difference between the experimental and control classes used the test described in the following: 
Determining the Hypothesis

$\mathrm{H}_{\mathrm{a}}$

: There is an effect of Realistic Mathematics Approach (PMR) using learning devices based on Malay riau weaving motifs on mathematics learning outcomes at Junior High School 6 Pekanbaru.

$\mathrm{H}_{0} \quad$ : There is no effect of Realistic Mathematics Approach (PMR) using learning devices based on Malay riau weaving motifs on mathematics learning outcomes at Junior High School 6 Pekanbaru.

Determine Significant Level

The significant level for testing the hypothesis in this study uses the confidence $\alpha=0.05$.

Basis of Decision Making and Decision Making

1. If $\mathrm{Sig}>\alpha$, then $\mathrm{H}_{0}$ is accepted.

2. If $\mathrm{Sig}<\alpha$, then $\mathrm{H}_{0}$ is rejected.

For decision making, a hypothesis test calculation will be carried out using an independent sample $\mathrm{t}$ test in the SPSS 22 program.

Table 7. Output of t-test Data Post-test

\begin{tabular}{|c|c|c|c|c|c|c|c|c|c|}
\hline \multicolumn{10}{|c|}{ Independent Samples Test } \\
\hline & $\begin{array}{l}\text { Levene's } \\
\text { Test for } \\
\text { Equality }\end{array}$ & \multicolumn{8}{|c|}{ t-test for Equality of Means } \\
\hline & \multirow{2}{*}{ (1) } & \multirow[b]{2}{*}{ Sig. } & \multirow[b]{2}{*}{$\mathrm{t}$} & \multirow[b]{2}{*}{$\mathrm{df}$} & \multirow{2}{*}{$\begin{array}{c}\text { Sig. } \\
(2- \\
\text { tailed) }\end{array}$} & \multirow{2}{*}{$\begin{array}{c}\text { Mean } \\
\text { Difference }\end{array}$} & \multirow{2}{*}{$\begin{array}{l}\text { Std. Error } \\
\text { Difference }\end{array}$} & \multicolumn{2}{|c|}{$\begin{array}{l}95 \% \\
\text { Confidence } \\
\text { Interval of the } \\
\text { Difference }\end{array}$} \\
\hline & & & & & & & & Lower & Upper \\
\hline $\begin{array}{c}\text { Equal } \\
\text { variances } \\
\text { assumed }\end{array}$ & .101 & .752 & 3.287 & 76 & .002 & 8.667 & 2.637 & 3.415 & 13.918 \\
\hline $\begin{array}{c}\text { Equal } \\
\text { variances } \\
\text { not } \\
\text { assumed }\end{array}$ & & & 3.287 & 75.688 & .002 & 8.667 & 2.637 & 3.415 & 13.918 \\
\hline
\end{tabular}

Based on table 6 above, the results of the SPSS output on the pre-test and post-test values obtained Sig. (2-tailed) 0.604 and 0.002. while the value of $\alpha=0,05$ means $0.002<0.05$, so it can be concluded that $\mathrm{HO}$ is rejected and means $\mathrm{Ha}$ is accepted, then there is an effect of applying the Realistic Mathematics Approach using learning devices based on Riau Malay weaving motifs on the learning outcomes of mathematics at Junior High School 6 Pekanbaru. 


\section{Discussion}

From a series of research processes that have been carried out, obtained several important things that the teacher should pay attention to in teaching in the classroom. It turns out that students are very interested in new things such as the appearance of culture-based mathematics material on student worksheets. They are very enthusiastic in carrying out a series of activities in their LKPD, many are asking about the cultural elements that are raised. According to students learning mathematics from the local culture is very easy to understand and not boring. This research is very important to provide information to us that by taking learning that is fun, close to students' lives and directed can improve student academic achievement which can be seen in the improvement of student learning outcomes after the action is taken. The results of this study are in line with the initial hypothesis of the study and several relevant studies. Therefore, teachers can use this realistic mathematical approach in learning so that student learning outcomes increase.

\section{CONCLUSION}

Based on the results of the research and discussion that have been described, it can be concluded that the SPSS output results obtained the value of Sig. (2-tailed) 0.002 . while the reset value $\alpha=0,05$ means $0.002<0.05$, so it can be concluded that $\mathrm{H}_{0}$ is rejected and means $\mathrm{H}_{\mathrm{a}}$ is accepted, so that it is known that the Realistic Mathematics Approach (PMR) using a learning device based on Malay riau weaving motifs can improve mathematics learning outcomes in SMP Negeri 6. There are several suggestions that can be made. given by the researcher, which are as follows: 1) The application of the Realistic Mathematics Approach (PMR) using a learning device based on the Malay riau weaving motif gives positive results, namely it can improve students' mathematics learning outcomes, therefore this technique can be used as an alternative that can be applied by teachers for mathematics subjects in school. 2) The research should also pay attention to things that can motivate students in learning mathematics. Teachers must be able to motivate students when learning takes place. Especially when students will present the results of their discussions, this is because there are some students who have a poor level of confidence, so that during presentations they are nervous and tend to find it difficult to present the results of the discussions they have done in class. 3) When students' self-confidence is better, it will have a positive impact on student achievement in the material being studied.

\section{ACKNOWLEDMENTS}

Thank you to all those who have helped in carrying out the research and students who have participated in this research.

\section{REFERENCES}

Arikunto, S. (2013). Prosedur Penelitian Suatu Penelitian Praktik. Jakarta: Rineka Cipta.

Arsaythamby, V., \& Zubainur, C. M. (2014). How a Realistic Mathematics Educational Approach 
Affect Students' Activities in Primary Schools? Procedia - Social and Behavioral Sciences, 159, 309-313. https://doi.org/10.1016/j.sbspro.2014.12.378

Binsar, K., Darius, A., \& Adrianus, M. (2011). Budaya Melayu Riau untuk SMP Kelas VII. Solo: Inti Prima Aksara.

Bunga, N., Isrok'atun, \& Julia. (2016). Pendekatan Realistic Mathematics Education Untuk Meningkatkan Kemampuan Komunikasi Matematis Siswa. Jurnal Pena Ilmiah, 1(1), 441-450. https://doi.org/10.22460/jpmi.v1i5.p915-922

Martono, N. (2013). Metode Penelitian Kuantitatif. Jakarta: Kencana Prenadamedia Group.

Nunes, T., \& Bryan, P. (2000). Learning and Teaching Mathematics, An International Perspective. UK: Psychology Press.

Qian, K. W. (2019). Refugee Education in Another Perspective : the Current State in Malaysia and Its Way Forward. The Bulletin of the Graduate School, Soka University, 153-167.

Rajagukguk, W., \& Hazrati, K. (2021). Analisis Self-Efficacy Siswa dalam Penelitian Pembelajaran Matematika dengan Pendekatan Matematika Realistik dan Inkuiri. Jurnal Cendekia: Jurnal Pendidikan Matematika, 5(2), 2077-2089. https://doi.org/10.31004/cendekia.v5i2.761

Rezeki, S., Andrian, D., Wahyuni, A., \& Nurkholisah, H. (2020). The sustainability concept of Riau cultures through development of mathematics learning devices based on Riau folklore at elementary schools. Journal of Physics: Conference Series, 1538(1). https://doi.org/10.1088/1742$6596 / 1538 / 1 / 012066$

Sánchez-Compaña, M. a. T., Sánchez-Cruzado, C., \& García-Ruiz, C. R. (2020). An interdisciplinary scientific and mathematic education, addressing relevant social problems such as sexist hate speech. Information (Switzerland), 11(12), 1-16. https://doi.org/10.3390/info11120543

Setyosari, P. (2013). Metode Penelitian Pendidikan dan Pengembangan. Jakarta: Kencana Prenadamedia Group.

Sudaryono. (2016). Metode Penelitian Pendidikan. Jakarta: Prenadamedia Group.

Sugiyono. (2013). Metode Penelitian Kuantitatif, Kualitatif, dan R\&D. Bandung: Alfabeta.

Sugiyono. (2015). Metode Penelitian Pendidikan. Bandung: Alfabeta.

Wahyuni, A., \& Abadi, A. M. (2014). PERBANDINGAN KEEFEKTIFAN PEMBELAJARAN COOPERATIVE LEARNING TYPE STAD DAN TYPE TPS PADA PEMBELAJARAN BANGUN RUANG SISWA SMP. Jurnal Riset Pendidikan Matematika, 1(2), 164. https://doi.org/10.21831/jrpm.v1i2.2673

Wijaya, A. (2012). Pendidikan Matematika Realistik. Yogyakarta: Graha Ilmu.

Zafrullah, Z., \& Zetriuslita, Z. (2021). Learning interest of seventh grade students towards mathematics learning media assisted by Adobe Flash CS6. Math Didactic: Jurnal Pendidikan Matematika, 7(2), 114-123. https://doi.org/10.33654/math.v7i2.1272 